Original Article

\title{
Awareness on epidemiological factors of HIV/AIDS among nursing students in selected institutions in Dakshina Kannada
}

\section{Neetha Kamath}

Associate Professor, Department of Community Health Nursing, Nitte Usha Institute of Nursing Sciences, Nitte University, Mangalore

*Corresponding Author: Neetha Kamath, Associate Professor, Department of Community Health Nursing, Nitte Usha Institute of nursing Sciences, Nitte University, M angalore.

M obile: +919845472309 E-mail : neetha.jayavanth @gmail.com \& neethakamath@ nitte.edu.in

Received : :20-11-2015

Review Completed : 13-05-2016

Accepted : : 14-05-2016

Keywords : Awareness, Epidemiological factors of HIV, Nursing students

\begin{tabular}{|c|}
\hline Access this article online \\
\hline Quick Response Code \\
\hline
\end{tabular}

\begin{abstract}
:
Introduction : An integrated approach is strongly suggested for creating knowledge, attitudes, and awareness to control the spread of HIV/AIDS among young people as well as health care students.
\end{abstract}

Objectives: To determine the awareness on epidemiological factors of HIV/AIDS among nursing students.

\begin{abstract}
Methodology : A quantitative approach with descriptive design was found suitable to conduct the study among 700 first year B Sc nursing students were selected using cluster sampling method from different nursing institutions. After obtaining the consent from the subjects a pretested and valid questionnaire on HIV/AIDs was administered to collect the data.
\end{abstract}

Results : All the students had information (86.1\%) on HIV/AIDS mainly from TV/Radio. It was found that majority of the subjects (63.3\%) had poor awareness, $31.6 \%$ had average and only $5.1 \%$ of subjects had good awareness on HIV/AIDS.

Conclusion : It is evident from the study findings that the nursing students lack awareness on epidemiological factors of HIV/AIDs there is a need to have an education program before they are active in caring for the patient in hospital.

\section{Introduction}

India is the third country in the world and first in Asia which has 2.1 million people infected with HIV/AIDS. It accounts for about four out of 10 people infected with the deadly virus according to a UN report 2014. The report by UNAIDS, said that 19 million of the 35 million people living with the virus globally do not know their HIV_- positive status and so ending the AIDS epidemic by 2030 (UN GAP report, 2014). The infection among children account for 3.5\% and $83 \%$ among the adult population between the ages of 15-49 years with the prevalence rate among adult is $0.31 \%$ (UN report, 2013). Karnataka is the fifth high prevalent state where approximately 2.5 lakhs people are living with HIV/AIDS. Though the total numbers are high in the south, the number of fresh cases being recorded every year has dropped significantly since 2010. According to the health ministry, Andhra Pradesh, Maharashtra, Tamil Nadu and
Karnataka also saw a sharp fall in the number of fresh cases reported every year. The total number new cases has reduced almost $50 \%$ across the country in three years-from 3.1 lakh fresh cases in 2010-11 to 1.5 lakh cases in 2013-14.

Scientific information and productive life skills are needed to educate the university students regarding the health consequences of HIV/AIDS. An integrated approach is strongly suggested for creating knowledge, attitudes, and awareness to control the spread of HIV/AIDS among young people as well as health care students (Kumar.2003).Nurses are key health care workers in health industry. They spend most of their time with the patients which enable them to take care the physical, social and psychological aspects of patients. Therefore they need to know about comprehensive knowledge about the epidemiological factors of various communicable and non- 
communicable diseases. The nursing students should be prepared adequately in taking care of patients with HIV/AIDS. It was reported that the nursing students should receive training in sensitivity, communication skills, and the development of compassionate attitudes toward HIV infected patients. Studies in India concerning HIV-related knowledge and attitudes amongst both health professionals suggest that early educational intervention has the potential to address the gaps both in knowledge and the negative attitudes directed towards those with HIV infection (Sanath, 2012). In India many studies have conducted among the nursing students knowledge on HIV reported that participants had the misconception that HIV transmission is possible through hugging, sharing toilet seats, towels, utensils and shaking hands with HIV infected patients. Students said that vaccine is available for HIV/AIDS and it is curable. It was also reported that they were afraid of cross infection in giving nursing care to HIV/AIDS and ART in PEP for HIV/AIDS is not useful (Anvitha $K, 2012$ ). In this regard with the above view, the present study was conducted with the objective to assess the awareness among newly admitted nursing undergraduates to remove apprehension, build up confidence so as to enhance their ability to provide care to patients with the disease.

\section{Materials and Methods}

In this non experimental cross sectional study design, the freshly admitted nursing undergraduates were taken as study subjects. The students were of first year Bsc Nursing students of consecutive two years i.e. of year 20012 and 2013. The subjects were selected using cluster sampling technique. The investigator collected the list of all colleges of Dakshina Kannada district and requested to give permission to conduct the study. The investigator received positive reply from fifteen nursing colleges. Then eight colleges were taken by simple random technique. Total 700 students were enrolled in the study as study subjects. Ethical clearance certificate was obtained from central ethical committee of Nitte University to conduct the study. After explaining the nature and purpose of the study informed consent was obtained from study subjects. A pretested, valid and structured questionnaire was used to collect the data from nursing students. There were forty closed ended multiple choice questions included in the tool. Each correct answer was assigned one score. The collected data was entered in master data sheet and analysed using SPSS package.

\section{Results}

Among the 700 hundred nursing students majority of the subjects (83.6\%) were females residing in hostel (86.1\%) coming from nuclear family $(90.4 \%)$ belonging to Christian religion (84.4\%). All the students had information on HIV/AIDS and majority (86.1\%) had mainly from T.V/Radio

(Table 1). Awareness score of nursing students regarding HIV/AIDS are arbitrarily graded into poor, average and good grades. The finding of Table 2 shows that majority of the students had poor awareness 437 (62.7\%) on HIV/AIDSand only $43(6.1 \%)$ students had good awareness.

The awareness score was categorised into various areas of HIV/AIDS. The findings of Table 3 show that in the area of epidemiology the mean awareness score was $4.01 \pm 1.3$ whereas the awareness on mode of transmission was $3.39+1.2$. In the area of signs and symptoms the awareness score was $4.33 \pm 1.6$ where as in diagnosis $1.15 \pm 0.7$. In the area of management the score was $4.38 \pm 1.6$ where as in the area of control and prevention the score was $5.13 \pm 1.6$ respectively. This shows that the nursing students had comparatively better awareness in area such as diagnosis (57.5\%), epidemiology $(57.28 \%)$ and control and prevention (57\%) area.

The finding in Table 4 shows that the awareness level and calculated ${ }^{2}$ values of demographic variable such as gender $\left({ }^{2}=0.863 P=0.353\right)$, type of family $\left({ }^{2}=0.797, P=0.372\right)$, current resident $\left({ }^{2}=1.117, P=0.572\right)$, and source of information $\left({ }^{2}=0.746, P=0.388\right)$ was lesser than the 0.05 level. This shows that the association between the awareness level and demographic variables was not statistically significant at 0.05 levels

\section{Discussion}

The newly admitted nursing students who are directly 
Table 1 : Frequency and percentage of sample characteristics

$\mathrm{N}=700$

\begin{tabular}{|c|c|c|c|}
\hline SI no & Variable & Frequency & Percentage (\%) \\
\hline \multicolumn{4}{|c|}{1 Gender } \\
\hline & - Male & 115 & 16.4 \\
\hline & - Female & 585 & 83.6 \\
\hline \multicolumn{4}{|c|}{2 Religion } \\
\hline & - Hindu & 82 & 11.7 \\
\hline & - Christian & 590 & 84.4 \\
\hline & • M uslim & 28 & 3.9 \\
\hline \multicolumn{4}{|c|}{3 Type of Family } \\
\hline & - Nuclear & 633 & 90.4 \\
\hline & - Joint & 59 & 8.4 \\
\hline & - Extended & 8 & 1.1 \\
\hline \multicolumn{4}{|c|}{4 Current Residence } \\
\hline & - Home & 56 & 8.0 \\
\hline & - Hostel & 603 & 86.1 \\
\hline & - Paying Guest & 41 & 5.9 \\
\hline \multicolumn{4}{|c|}{5 Source of information } \\
\hline & • T.V/Radio & 603 & 86.1 \\
\hline & - Newspapers & 69 & 9.9 \\
\hline & - Friends/Parents & 28 & 4.0 \\
\hline
\end{tabular}

Table 2 : Frequency, percentage and Grading of awareness score of nursing students

$\mathrm{N}=700$

\begin{tabular}{|l|c|c|c|c|}
\hline Sl. No & $\begin{array}{c}\text { Awareness } \\
\text { score }\end{array}$ & Grade & Frequency & Percentage (\%) \\
\hline 1 & $0-20$ & Poor & 437 & 62.7 \\
\hline 2 & $21-30$ & Average & 220 & 31.2 \\
\hline 3 & $31-40$ & good & 43 & 6.1 \\
\hline
\end{tabular}

come from general population have relatively inadequate awareness on HIV/AIDS. The demographic characteristics shown that majority of the subjects (83.6\%) were females residing in hostel (86.1\%) hailing from nuclear family (90.4\%) belonging to Christian religion (84.4\%). All the students had information on HIV/AIDS and majority (86.1\%) had mainly from T.V/Radio which was similar to a study conducted (Ravishanker) in Nainital shows that the nursing students age ranged between 17 to 21 years with mean age of $18.20 \pm 0.88$ years. Majority of them i.e. 83 per cent were Sikh. M ost of them i.e. 97 per cent were $10+2$ pass, only 3 per cent of them were graduates. Majority of girls i.e. 74 per cent of them were from nuclear families. In the present study the mean awareness on mode of transmission was $3.39 \pm 1.2$ whereas in the area of signs and symptoms the awareness score was $4.33 \pm 1$.6. This was similar to a study conducted at Belgam (Kiran N) shows that
Table 3 : M ean, mean percentage and SD of area wise awareness score of nursing students regarding HIV/AIDS

$\mathrm{N}=700$

\begin{tabular}{|l|l|c|c|c|c|}
\hline Sl. & Area & Max & Mean & Mean \% & SD \\
\hline No & & score & & & \\
\hline 1 & Epidemiology & 7 & 4.01 & 57.28 & 1.3 \\
\hline 2 & Mode of Transmission & 6 & 3.39 & 56.5 & 1.2 \\
\hline 3 & Signs and symptoms & 8 & 4.33 & 54.12 & 1.6 \\
\hline 4 & Diagnosis & 2 & 1.15 & 57.5 & 0.7 \\
\hline 5 & Management & 8 & 4.38 & 54.75 & 1.6 \\
\hline 6 & Control and prevention & 9 & 5.13 & 57.0 & 1.6 \\
\hline
\end{tabular}

Table 4 : Association between the awareness level and demographic variables of nursing students

$\mathrm{N}=700$

\begin{tabular}{|c|c|c|c|c|c|}
\hline $\begin{array}{l}\text { SI } \\
\text { no }\end{array}$ & Variable & $\begin{array}{c}\text { Frequency } \\
\text { value }\end{array}$ & Calculated & P value & Significance \\
\hline 1 & $\begin{array}{l}\text { Gender } \\
\text { - Male } \\
\text { - Female }\end{array}$ & $\begin{array}{l}115 \\
585\end{array}$ & 0.863 & 0.353 & NS \\
\hline 2 & $\begin{array}{l}\text { Type of Family } \\
\text { - Nuclear } \\
\text { - Joint } \\
\text { - Extended }\end{array}$ & $\begin{array}{c}633 \\
59 \\
8\end{array}$ & 0.797 & 0.372 & NS \\
\hline 3 & $\begin{array}{l}\text { Current Reside } \\
\text { - Home } \\
\text { - Hostel } \\
\text { - Paying Guest }\end{array}$ & $\begin{array}{c}56 \\
603 \\
41\end{array}$ & 1.117 & 0.572 & NS \\
\hline 4 & $\begin{array}{l}\text { Source of infor } \\
\text { - T.V/Radio } \\
\text { - Newspapers } \\
\text { - Friends/Pare }\end{array}$ & $\begin{array}{r}\text { mation } \\
603 \\
69 \\
\text { hts } 28\end{array}$ & 0.746 & 0.388 & NS \\
\hline
\end{tabular}

knowledge about the mode of transmission was $97.0 \%$ in both the sexes. The belief about HIV/AIDS transmission is through handshake $(4.8 \%)$, sharing utensils (7.3\%), mosquito bite (19.5\%), and common tooth brush (14.6\%) and by kissing (12.1\%). Knowledge of prevention was adequate $63.4 \%$ in male students and $70.4 \%$ among female students. The present study focused that that the nursing students had comparatively better awareness in area such as diagnosis (57.5\%), epidemiology (57.28\%) and control and prevention (57\%) area which is true compared to a study conducted by (Sandeep Sachdev, 2011) at India reveals that that students were aware that infection neither spreads by social activities like handshake/playing nor by mosquito bite. However, low level was ascertained with regard to items related to non-curability of infection (57.4\%) and availability of anti-retro viral therapy (27.4\%) approximately. The association between the awareness 
level and demographic variables was not statistically significant at 0.05 levels. This reveals that the awareness level is independent of age, residence, type of family and source of information.

\section{Conclusion}

It is evident from the study findings that the nursing students lack awareness on epidemiological factors of HIV/AIDs. There is a need to have a comprehensive education program on signs and symptoms, mode of transmission, prevention and safety practices before they

\section{References}

1. Anvitha K, Raghavendraswamy K, Santhoshkumar A, Prashanth H L. A cross sectional study on awareness regarding pre and post exposure prophylaxis of HIV/AIDS among health care providers of McGann teaching hospital Shimoga Karnataka. Journal of public health 2012; 9(4): 45

2. Kiran $\mathrm{N}$ and etal. A cros sectional study HIV/AIDS among paramedical students of BIM SBelgaum. Journal of advance researches in biological sciences, 2013;5(4):336-340

3. Kumar R, Sanath V. Knowledge, attitude and practices towards HIV among nurses in atertiary care hospitals: two decades after the discovery .Journal of communicable diseases. 2002;34(4):245-56

4. Sachdev S, Malik J S, sachdev R, Sachdev T R. HIV/AIDS knowledge among first year MBBS, nursing, Pharmacy students of a health university, India. Journal of family community medicine. 2011:18(3); $155-158$

5. Shanker $R$ and etal. Awareness of HIV/AIDS among first year medical undergraduates in Nainital, India. Indian Journal of preventive social medicine. 2011;42(2)

6. Sharma S K, Kaur K, Kaur Manpreet. Awareness of HIV/AIDS among newly admitted nursing students. Nursing and midwifery research journal.2006: 2(1).

7. www.naco.org

8. WWW.UNGAP.2014 are active in caring for the patient in hospital. The nursing students in first year are not exposed to patients. Their awareness on cause, spread, control and prevention of HIV/AIDS are not satisfactory. The training will create awareness and inculcate positive attitude among students before they start caring for the sick in the hospital. This helps them to prepare themselves to face the global challenge of HIV pandemic. Meanwhile they will be also aware about the use of personal protective devices and also protecting themselves getting any occupational exposure hazards. 